\title{
THE INFLUENCE OF ALUMINUM DROSS ON MECHANICAL AND CORROSION PROPERTIES OF CEMENT PASTE: PART I
}

\section{Trinet Yingsamphancharoen}

Department of Materials Engineering, Faculty of Engineering, Kasetsart University, 50 Ngamwongwan Rd., Ladyao, Chatuchak, Bangkok 10900, Thailand Center of Welding Engineering and Metallurgical Inspection, Science and Technology

Research Institute, King Mongkut's University of Technology North Bangkok, 1518Pracharat 1 Road, Wongsawang, Bangsue, Bangkok 10800, Thailand

\section{Aphichart Rodchanarowan*}

Department of Materials Engineering, Faculty of Engineering, Kasetsart University, 50 Ngamwongwan Rd., Ladyao, Chatuchak, Bangkok 10900, Thailand *Corresponding Author: fengacrw@ku.ac.th

\begin{abstract}
In this study, aluminum dross, which is an industrial waste product from the aluminum casting industry, is used as an admixture in cement paste to observe its effects on the mechanical properties and the corrosion resistance in the reinforced steel bars. The mass ratios of cement and aluminum dross used to prepare the cement paste with the controlled water ratio of $48.5 \mathrm{wt}$.\%are1.00:0.05, 1.00:0.1, and 1.00:0.2. The effect the mass ratios of cement and aluminum dross and the average particle sizes of the aluminum dross (<45, 60 and $90 \mu \mathrm{m}$ in diameter) on porosity, bulk density, compressive strength, and corrosion on the reinforced steel bars have been centered around. The results show that as the quantity of the aluminum dross increases, the porosity of cement paste increases but the bulk density and compressive strength of the paste decrease. In addition, as the particle size of the aluminum dross increases, both pore's size and bulk density increase but the compressive strength decreases. Nevertheless, it found that the addition of aluminum dross to the cement paste causes more corrosion on reinforced steel bar and also more fractured on cement paste.
\end{abstract}

Keywords: Aluminum Dross, Cement Paste, Corrosion, Mechanical Properties

Cite this Article: Trinet Yingsamphancharoen and Aphichart Rodchanarowan, The Influence of Aluminum Dross on Mechanical and Corrosion Properties of Cement Paste: Part I. International Journal of Advanced Research in Engineering and Technology, 10(6), 2019, pp. 192-201

http://iaeme.com/Home/issue/IJARET?Volume $=10 \&$ Issue $=6$ 


\section{INTRODUCTION}

Cement paste and concrete are one of the most commonly used construction materials since the last decade [1]. They have been applied in several types of constructions such as building, road, dam, bridge, etc [1-2]. Cement paste is generally prepared by mixing both cement and water altogether. The mixture initially behaves like a fluid for a period, which beneficially allows the paste to be poured into mold and later set into desired shape.

The attempt of utilizing high silica and alumina compounds as admixtures from natural sources (bagasse fibers or particles) and industrial wastes (metal or ceramics particles) has been reported in the literatures [2-8]. There are several reasons for utilization such mentioned admixtures, which includes the value adding to such compounds or wastes, to recycle instead of disposing it, and to improve the mechanical properties of cement paste or concrete.

Any waste from aluminum industries is of particular interests to be used as an admixture in improving mechanical or other properties in cement pastes or even in concrete. This is due to the fact that aluminum waste from smelting, foundry, and injection process possess high durability, low density and good reflection property along with refractory [9]. Previously, it was reported that mixing of aluminum into cement paste results in the increase in the porosity in the cement paste, which consequently causes the weight's reduction [2,10-13]. Apart from that, corrosion of reinforced steel bar continues to be problematic in the reinforced concrete structure and consequently is a concern for scientists and engineers to pay a closer attention [14-15]. To the best knowledge, there is no reports have been evaluated the effect of admixtures, especially from natural resources as well as industrial waste on both mechanical and corrosion properties.

In this study, the waste from aluminum foundry industries, which is called aluminum dross, is used to investigate by mixing it into cement paste. In particular, the focus of this study is to investigate the effect of aluminum dross admixture on the porosity, bulk density, compressive strength, and corrosion behavior of the cement paste.

\section{EXPERIMENTAL}

The portland cement used in this study is type 1. For the admixture, the aluminum dross is obtained from the foundry industry and sieved through meshes to obtain the desired average particle sizes for performing the experiments. The aluminum dross particles have been screened and classified into 3 sizes: the average particle sizes of $<45 \mu \mathrm{m}$ in diameter (sieve mesh $<45$ $\mu \mathrm{m}), 60 \mu \mathrm{m}$ in diameter $(45 \mu \mathrm{m}<$ sieve mesh $<75 \mu \mathrm{m})$, and $90 \mu \mathrm{m}$ in diameter $(75 \mu \mathrm{m}<$ sieve mesh $<106 \mu \mathrm{m})$. The cement paste is prepared using tap water to mix both aluminum dross and Portland cement.

The chemical compositions of cement powder and aluminum dross are analyzed using Xray analytical microscope technique with X-ray Fluorescence (XRF: Horiba X-ray analytical microscope XGT-2000W) as shown in Table 1. Table 1 shows that the main chemical compositions found in cement is the same as in aluminum dross, which consists of aluminum oxide $\left(\mathrm{Al}_{2} \mathrm{O}_{3}\right)$, silica dioxide $\left(\mathrm{SiO}_{2}\right)$, ferric oxide $\left(\mathrm{Fe}_{2} \mathrm{O}_{3}\right)$ and calcium oxide $(\mathrm{CaO})$.

For the cement paste's preparation followed by the ASTM C109, the water ratio for making cement paste is $0.485 \mathrm{wt} . \%$. In this study, the ratios of cement and aluminum dross have also been controlled for the investigations to three different compositions; $1.00: 0.05,1.00: 0.1$, and 1.00:0.2, which is referred to $5 \%, 10 \%$, and $20 \%$ aluminum dross's addition, respectively.

The density of cement paste is measured by using an electronic densimeter with $0.001 \mathrm{~g} / \mathrm{cm}^{3}$ resolution. The porosity is analyzed by using an image analyzer software as is Image-Pro version 4.5.0.29, which is released by Media Cybernetics, Inc. In addition, the topography's investigation is obtained by using a scanning electron microscope (SEM: Philips XL 30 series). 
In addition, the compressive strength's analysis is conducted by the use of universal testing machine (UTM H50KS, Hounsfield)

Table1 Chemical compositions of the cement and aluminum dross analyzed by XRF.

\begin{tabular}{|c|c|c|}
\hline \multirow{2}{*}{ Chemical Compositions } & \multicolumn{2}{|c|}{ Contents (\%) } \\
\cline { 2 - 3 } & Cement & Aluminum dross \\
\hline aluminum oxide $\left(\mathrm{Al}_{2} \mathrm{O}_{3}\right)$ & 41.830 & 85.549 \\
\hline silicon dioxide $\left(\mathrm{SiO}_{2}\right)$ & 53.088 & 10.550 \\
\hline ferric oxide $\left(\mathrm{Fe}_{2} \mathrm{O}_{3}\right)$ & 2.764 & 1.151 \\
\hline calcium oxide $(\mathrm{CaO})$ & 2.153 & 2.025 \\
\hline zinc oxide $(\mathrm{ZnO})$ & 0.050 & 0.531 \\
\hline copper oxide $(\mathrm{CuO})$ & - & 0.023 \\
\hline others & 0.115 & 0.171 \\
\hline
\end{tabular}

In addition, the tested corrosive solution for the mass loss and electrochemical measurements is the $3.5 \mathrm{wt} . \% \mathrm{NaCl}$. The reinforced steel bar used in this study is the one commonly used for the construction. The configuration for sample's preparation of the corrosion investigation is shown in Fig. 1. The duration times used for the experiments are 30, 60,90 , and 120days for both mass loss test and electrochemical measurements. The counter and reference electrode used for the electrochemical measurements are Pt counter electrode and the $\mathrm{Ag} / \mathrm{AgCl}(3 \mathrm{M} \mathrm{KCl})$ reference electrode, respectively. The potentiostat instrument used for the electrochemical experiments is the AutoLab (PGSTAT302N).
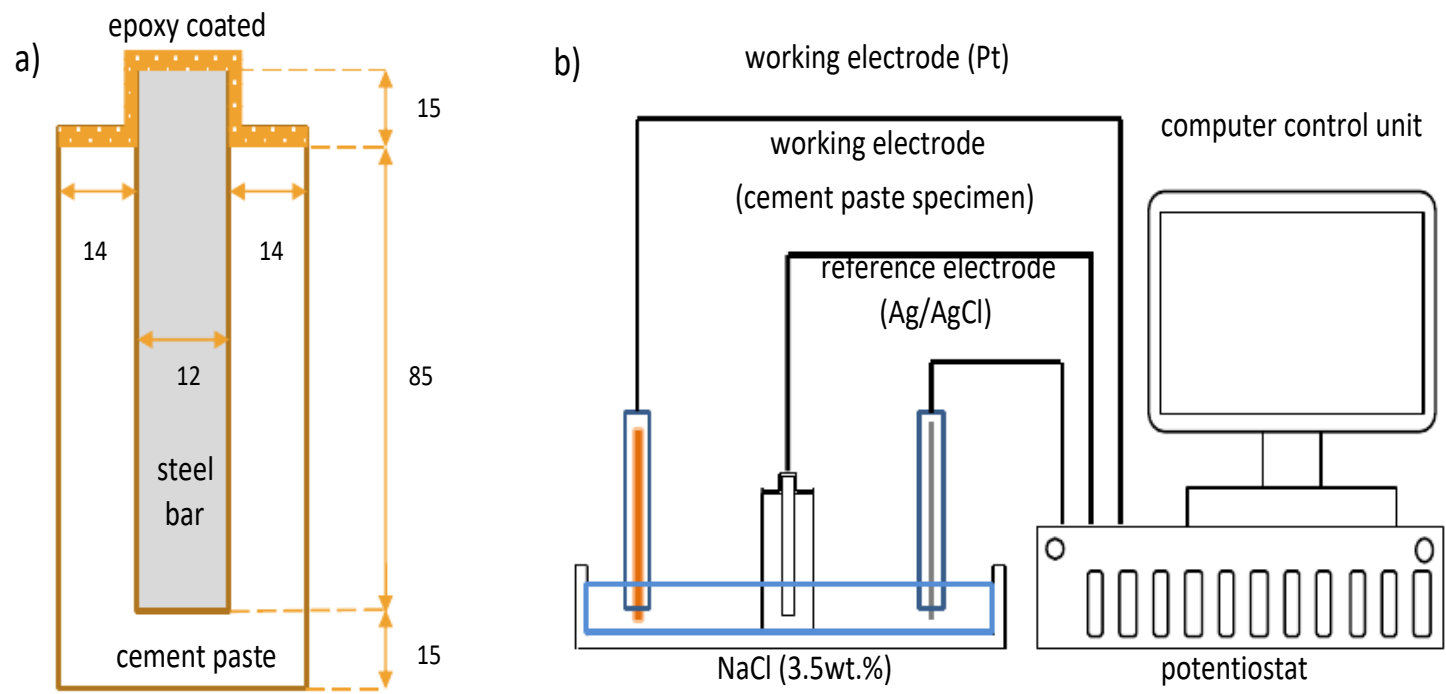

Figure 1 Configuration for specimen's preparation (a) reinforced steel bar cement paste and

(b) the electrochemical measurement.

\section{RESEULTS AND DISCUSSION}

\subsection{Chemical Analysis of the Materials by XRD}

The XRD patterns of the cement paste and cement paste mixed with the aluminum dross for different average particle sizes of $<45,60$, and $90 \mu \mathrm{m}$ are depicted in Fig. 2, Fig.3, and Fig. 4, respectively. As depicted in Fig. 2, the cement paste and the cement paste mixed with aluminum dross (average diameter $<45 \mu \mathrm{m}$ ) do not indicate any significant difference in terms of chemical composition. Also, the cement paste and the cement paste mixed with aluminum dross with 
average diameter of $60 \mu \mathrm{m}$ do not indicate any significant difference in terms of chemical composition as shown in Fig.3. In addition, the cement paste and the cement paste mixed with aluminum dross with the average diameter of $90 \mu \mathrm{m}$ do not indicate any significant difference in terms of chemical composition as represented in Fig. 4.

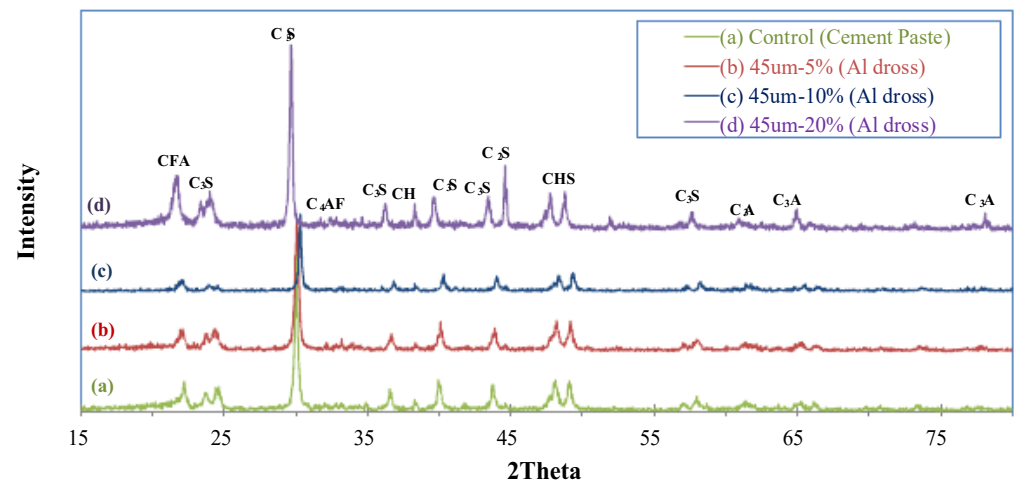

Figure 2 XRD patterns of (a) cement paste and cement paste mixed with the average particle size of aluminum dross $<45 \mu \mathrm{m}$ at different amount of aluminum dross: (b) $5 \%$ aluminum dross's addition,

(c) $10 \%$ aluminum dross's addition, and (d) $20 \%$ aluminum dross's addition.

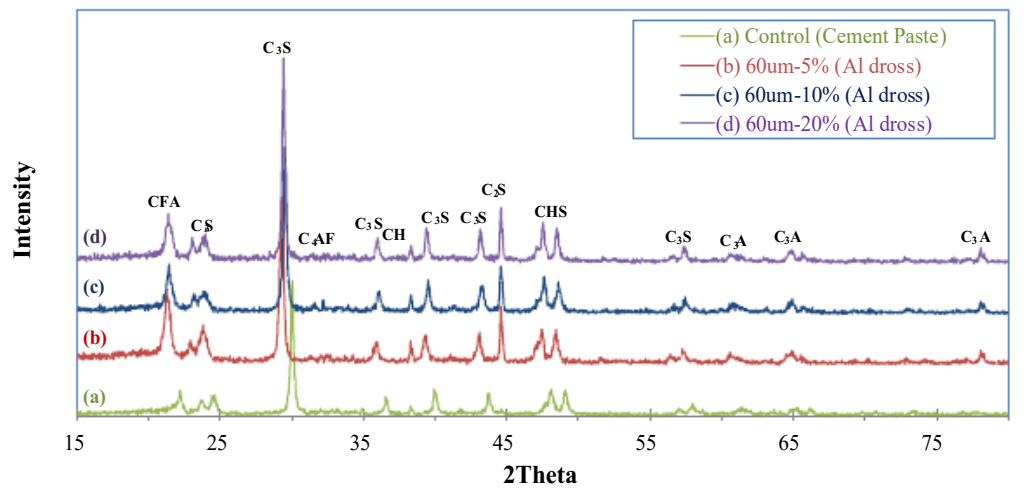

Figure 3 XRD patterns of (a) cement paste and cement paste mixed with the average particle size of aluminum dross of $60 \mu \mathrm{m}$ at different amount of aluminum dross: (b) 5\% aluminum dross's addition,

(c) $10 \%$ aluminum dross's addition, and (d) $20 \%$ aluminum dross's addition.

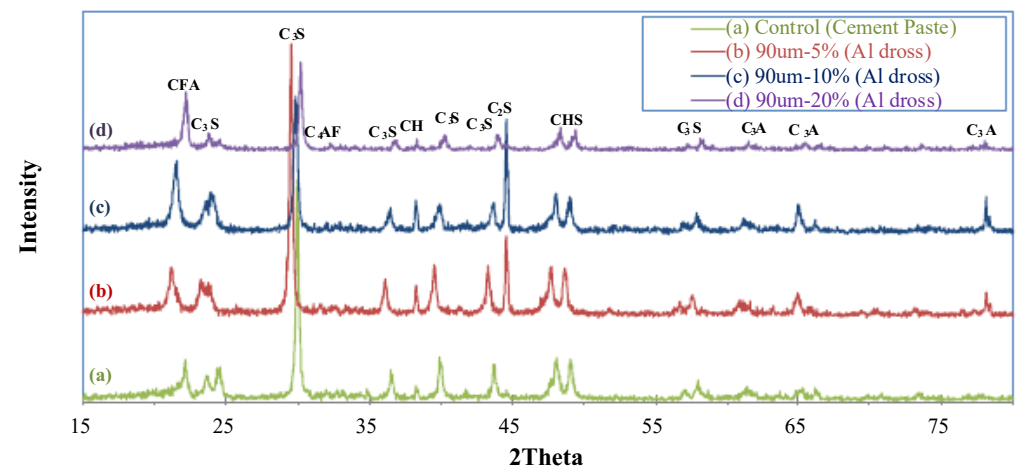

Figure 4 XRD patterns of (a) cement paste and cement paste mixed with the average particle size of aluminum dross of $90 \mu \mathrm{m}$ at different amount of aluminum dross: (b) 5\% aluminum dross's addition, (c) $10 \%$ aluminum dross's addition, and (d) $20 \%$ aluminum dross's addition. 
As demonstrated in Fig.2, Fig.3, and Fig.4, the addition of the aluminum dross into the cement in order to make cement paste cannot cause the significant change in terms of chemical compositions, which mostly contains the phased of calcium sulfoaluminate (CFA), tricalciumsilicate $\left(\mathrm{C}_{3} \mathrm{~S}\right)$, calcium hydroxide $(\mathrm{CH})$, calcium silicate hydrate $(\mathrm{CSH})$, and tetracalciumaluminoferrite $\left(\mathrm{C}_{4} \mathrm{AF}\right)$; however, the phases of dicalciumsilicate $\left(\mathrm{C}_{2} \mathrm{~S}\right)$ and tricalciumaluminate $\left(\mathrm{C}_{3} \mathrm{~A}\right)$ are presently observed when the addition of aluminum dross is conducted. The addition of admixture with high oxides of aluminum and silicon will not obstruct the hydration reaction between cement and water [16-17].

\subsection{Bulk Density and Compressive Strength of the Cement Paste}

The bulk density of the cement paste mixed with the aluminum dross at different particle size and different quantities is demonstrated in Fig.5. Based upon Fig.5, the mixed cement paste with aluminum dross exhibits lower bulk density than the unmixed cement paste. In addition, for the same particle size of aluminum dross's addition to the cement paste, the increase of the amount of aluminum dross mixed to the cement paste results in the increase of the bulk density. Furthermore, for the same amount of aluminum dross's addition to the cement paste, the bulk density seems to be higher as the particle size of the aluminum dross is higher.

The chemical reaction between aluminum dross and water resulted in hydrogen gas, which is later on initiated the air entrainment in the cement paste apart from the air from the environment [18-20]. Based on the above situation, this leads to the porosity's observation in a sufficient level when adding the aluminum dross. The more quantity of aluminum dross is mixed in the cement paste, the bigger average pore's size. Based on the experiment as seen in Table 2, the average pore's sizes in the case of adding $5 \mathrm{wt} . \%, 10 \mathrm{wt} . \%$, and $20 \mathrm{wt} . \%$ of aluminum dross to the cement paste using Image-Pro (version 4.5.0.29) are approximately 133, 281 , and $452 \mu \mathrm{m}$ in diameter, respectively. Hence, it is conceivable that the porosity's density is expected to be higher when the average pore's sizes is lowered [2,21]. Since the smaller particles allow for more water to be in contact with the surface area, the chemical reaction occurs at a faster rate and produces a large amount of entrain air. In contrast the larger sized particles have less surface area in contact with water the chemical reaction therefore requires more time to occur, resulting in a smaller number of large pores.

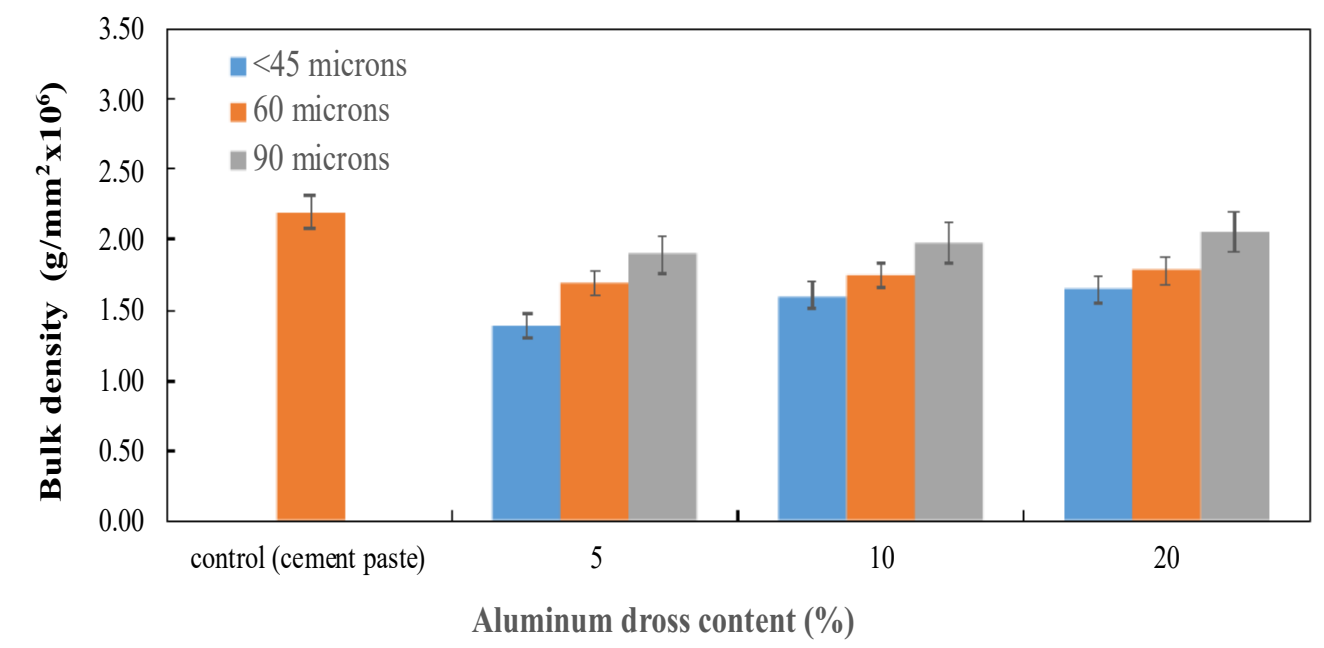

Figure 5 Effect of different aluminum dross contents (5\%, 10\%, and 20\% aluminum dross's addition) on bulk density of cement paste mixed with aluminum dross at different particle sizes.

http://iaeme.com/Home/journal/IJARET 196 editor@iaeme.com


This is why the bulk density increases as adding more aluminum dross to the cement paste for the same particle size of aluminum dross's addition to the cement paste. Additionally, such an observed trend might be due to the fact that the amount of water to react with the high ratios of cement and aluminum dross is not sufficient enough and leads a lot of unreacted portions, which consequently yields higher bulk density.

Table 2 The average pore's size in the cement paste mixing with 5\% aluminum dross's addition.

\begin{tabular}{|c|c|}
\hline $\begin{array}{c}\text { Average particle size of aluminum dross } \\
\text { in diameter }(\boldsymbol{\mu m})\end{array}$ & \begin{tabular}{c} 
Average pore's size $(\boldsymbol{\mu m})$ \\
\hline$<45$
\end{tabular} \\
\hline 60 & 133 \\
\hline 90 & 281 \\
\hline
\end{tabular}

The compressive strength of the cement paste mixed with the aluminum dross at different particle size and different quantities after 28 days of curing time is demonstrated in Fig.6. Based upon Fig.6, for the same amount of aluminum dross's addition to the cement paste, the compressive strength seems to be lower as the particle size of the aluminum dross is higher. In addition, for the same particle size of aluminum dross's addition to the cement paste, the increase of the amount of aluminum dross mixed to the cement paste results in a decrease in compressive strength. These observations are due to the fact that the high ratio of aluminum dross to cement creates bigger pores as mentioned in the discussion of Fig.5. Having more pores in the matrix creates less homogeneity in the cement paste, which consequently makes the compressive strength becomes lower. At any rate, the mixed cement paste with aluminum dross impressively exhibits higher compressive strength than the unmixed cement paste in a significant degree.

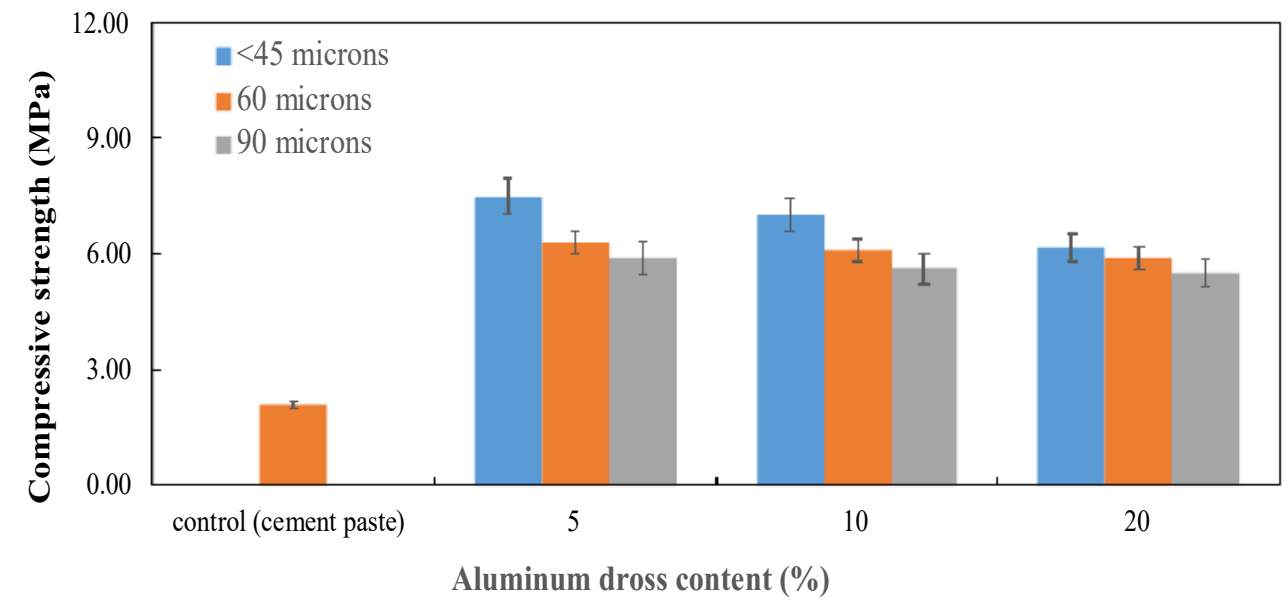

Figure 6 Effect of different aluminum dross contents (5\%, 10\%, and 20\% aluminum dross's addition) on compressive strength of cement paste mixed with aluminum dross after 28 days of curing time

(the average particle size of aluminum dross $<45 \mu \mathrm{m}$ ).

\subsection{Corrosion behavior of Reinforced Steel bar in Cement Paste}

The mass loss of the reinforced steel bar in the cement paste in the $3.5 \mathrm{wt} . \% \mathrm{NaCl}$ is investigated for different immersion times (30, 60, 60, and 120 days). Based upon Fig.7, mixing of aluminum dross in the cement paste does not prevent corrosion to occur in the reinforced steel 
bar. In fact, the addition of aluminum dross speeds up the corrosion even more. This might be due to the fact that the more pores in the matrix can enhance the encapsulation of the corrosive environments such as moist, $\mathrm{Na}^{+}, \mathrm{Cl}^{-}$, and other possible species in the matrix more than the less pores in the matrix. By having such a situation, the corrosion can then be accelerated than usual.

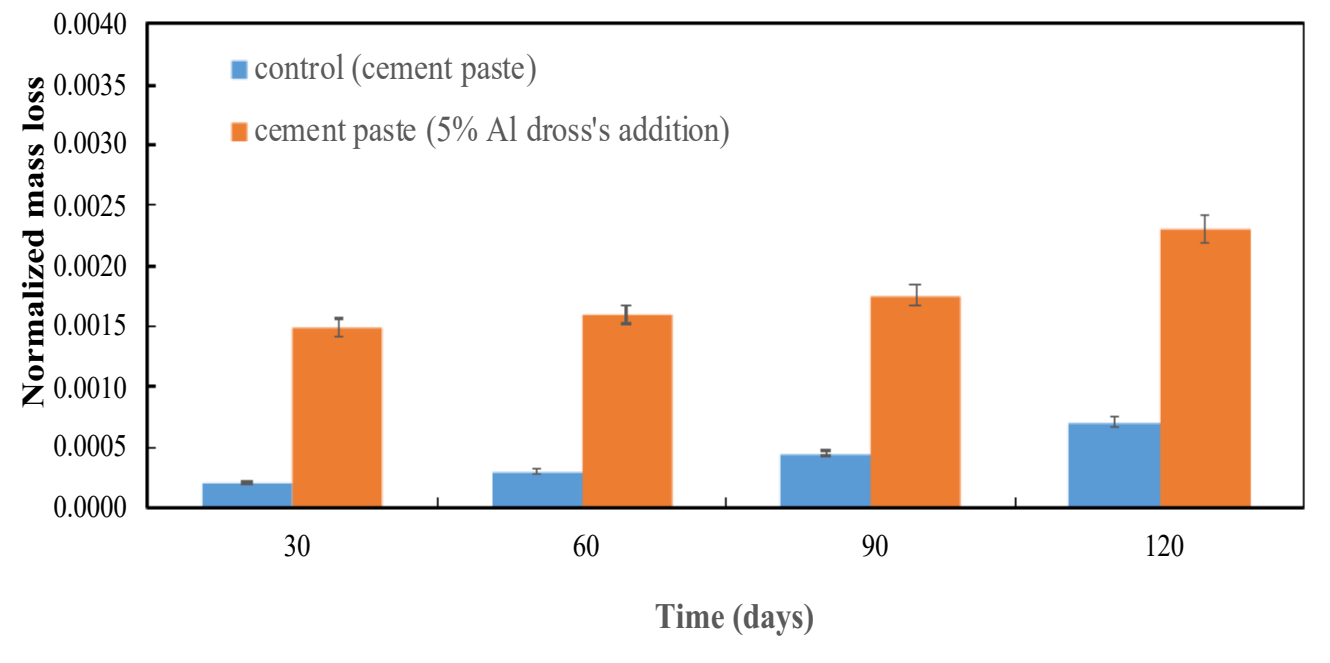

Figure 7 Comparison of normalized mass loss of reinforced steel bar in the cement paste and in the cement, paste mixed with $5 \mathrm{wt} . \%$ aluminum dross after soaking in $3.5 \mathrm{wt} . \% \mathrm{NaCl}$ solution for several duration times of $30,60,90$, and 120 days (the average particle size of aluminum dross $<45 \mu \mathrm{m}$ ).

The SEM images are further discussed in terms of the topographical and fractographical analysis as depicted in Fig.8. As the immersion time increases, the cement paste mixed with 5 wt. $\%$ aluminum dross (the average particle size $<45 \mu \mathrm{m}$ ) becomes more cracked and loosened up in the matrix's texture. Hence corrosive species are more independent to diffuse in the cement paste and to damage the reinforced steel bar [22].
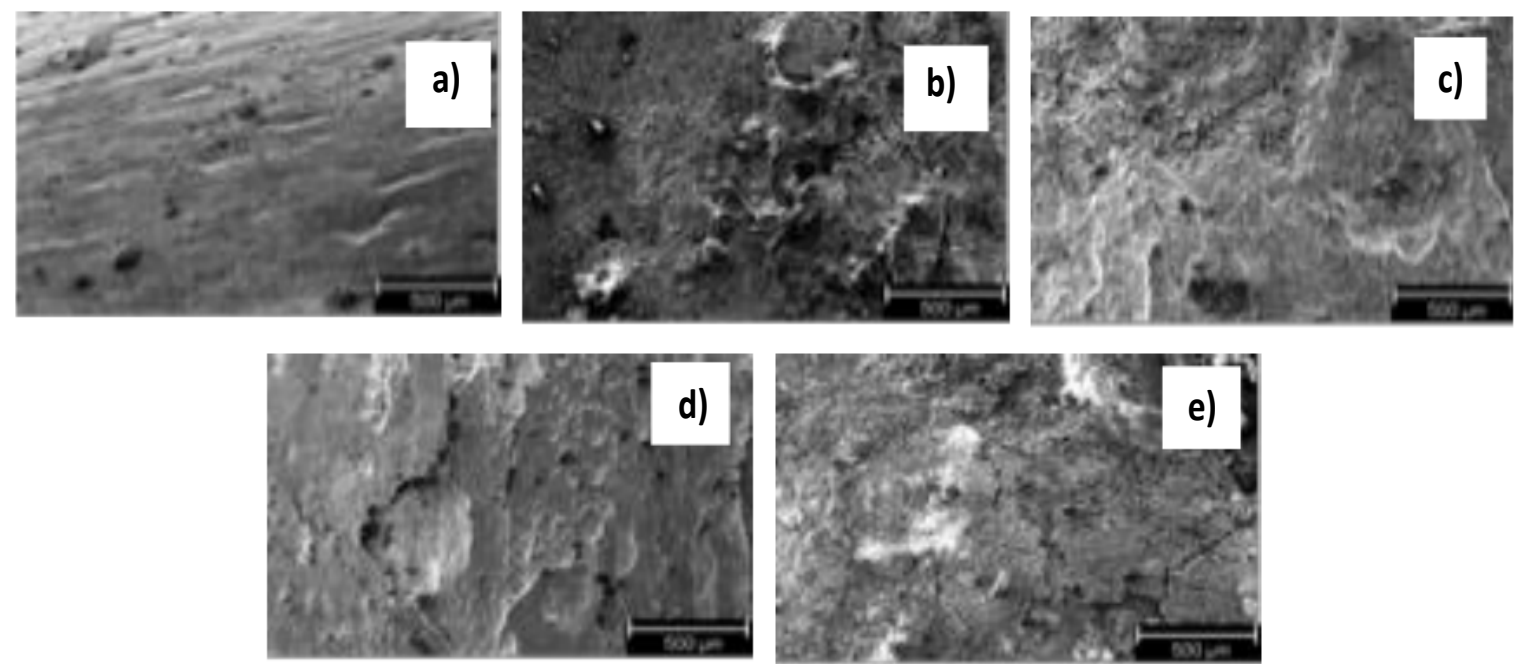

Figure 8 Corrosion of reinforced steel bar in cement paste mixed with aluminum dross (the average particle size of aluminum dross $<45 \mu \mathrm{m}$ ) a) before, and after immersing in $3.5 \mathrm{wt} . \% \mathrm{NaCl}$ solution for several immersion times: b) 30 days, c) 60 days, d) 90 days, and e) 120 days. 
From the electrochemical measurements as shown in Fig.9 in terms of potentiodynamic scans for several immersion times (30,60, 60, and 120 days) of reinforced steel bar cement paste with the addition of aluminum dross, the information regarding the corrosion potential $\left(\mathrm{E}_{\text {corr }}\right)$ and the corrosion current density $\left(\mathrm{i}_{\text {corr }}\right)$ can be obtained using the Tafel slope analysis.

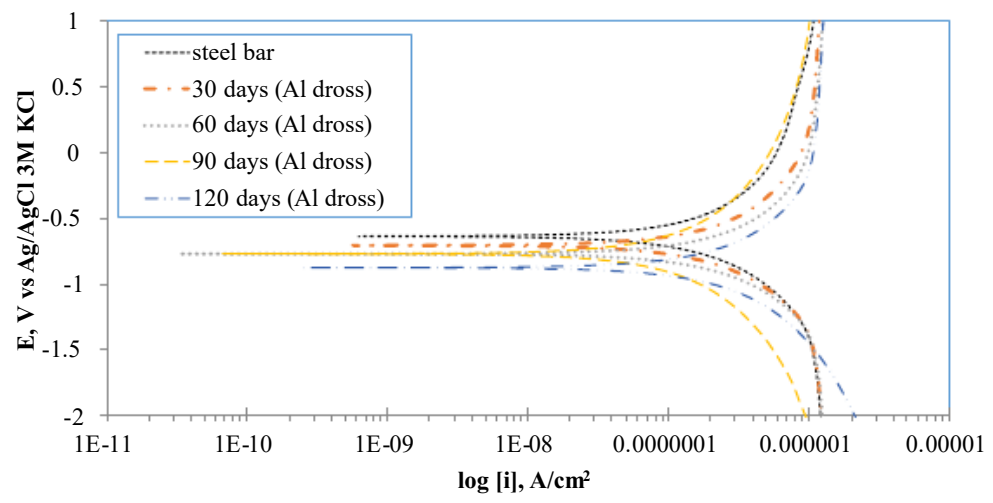

Figure 9 Potentiodyanmic scans of several reinforced steels in cement paste and cement pastes mixed with aluminum dross after immersion in $3.5 \mathrm{wt} . \% \mathrm{NaCl}$ solution for $30,60,90$, and 120 days

(the average particle size of aluminum dross $<45 \mu \mathrm{m}$ and 5\% aluminum dross's addition).

As summarized in Table 3 , as the immersion time increases, the $E_{\text {corr }}$ value decrease but the $\mathrm{i}_{\text {corr }}$ value increases, which is observed for not only mixing aluminum dross in the cement paste but also without addition aluminum dross. In addition, Table 3 also reveals that the addition aluminum dross to the cement paste enhance the corrosion to occur in a significant rate. This is due to that fact that the silica and alumina from aluminum dross cause more chance of pozzolanic reaction to take place, which consequently requires more calcium hydroxide. Such situation leads to lower $\mathrm{pH}$ or more acidic in the system and initiates more corrosive environments for the corrosion of reinforced steel bar inside the cement paste [23-24].

Table 3 The summary of $E_{\text {corr }}$ and $i_{\text {corr }}$ of reinforced steel bars in cement pastes mixed with aluminum dross after immersion in $3.5 \mathrm{wt} . \% \mathrm{NaCl}$ solution for 30, 60, 90, and 120 days (the average particle size of aluminum dross $<45 \mu \mathrm{m}$ and $5 \%$ aluminum dross's addition).

\begin{tabular}{|c|c|c|c|c|}
\hline \multirow{2}{*}{$\begin{array}{c}\text { Immersion } \\
\text { Times (day) }\end{array}$} & \multicolumn{2}{|c|}{ Control (Cement paste only) } & \multicolumn{2}{c|}{ Cement Paste (Aluminum dross) } \\
\cline { 2 - 5 } & $\mathbf{E}_{\text {corr }}(\mathbf{V v s} \mathbf{A g} / \mathbf{A g C l})$ & $\mathbf{i}_{\text {corr }}\left(\mathbf{A} / \mathbf{c m}^{2}\right)$ & $\mathbf{E}_{\text {corr }}(\mathbf{V} \mathbf{~ v s ~ A g / A g C l})$ & $\mathbf{i}_{\text {corr }}\left(\mathbf{A} / \mathbf{c m}^{2}\right)$ \\
\hline 30 & -0.62 & $1.02 \times 10^{-7}$ & -0.75 & $7.70 \times 10^{-7}$ \\
\hline 60 & -0.64 & $1.51 \times 10^{-7}$ & -0.77 & $8.40 \times 10^{-7}$ \\
\hline 90 & -0.70 & $2.01 \times 10^{-7}$ & -0.77 & $1.30 \times 10^{-6}$ \\
\hline 120 & -0.69 & $2.22 \times 10^{-7}$ & -0.83 & $2.40 \times 10^{-6}$ \\
\hline
\end{tabular}

\section{CONCLUSION}

The addition of aluminum dross into the cement paste results in more porosity in the cement paste than that without the addition. By having more pores in the cement past, the bulk density of the cement paste becomes higher. Nevertheless, more pores in the cement paste definitely causes less compressive strength of the cement paste. The corrosion on the reinforced steel bar are greatly enhanced by pores in the cement paste. To summarize the study, adding admixtures can improve mechanical properties of the cement paste but it can damage the reinforced steel bar if the pore's formations in the cement paste are much generated. 


\section{ACKNOLEDGEMENT}

This work was financially supported by Kasetsart University Research and Development Institute (KURDI), Kasetsart University. The authors would like to thank the faculty of engineering, Kasetsart University, for the supports of instruments and facility. In addition, the assistance from Miss Benjaporn Inseemeesak and Mr.Parinya Boonsa is greatly acknowledged.

\section{REFERENCES}

[1] J.J. Biernacki, J.W. Bullard, G. Sant, N. Banthia, K. Brown, et al., Cement in the $21^{\text {st }}$ century: challenges, perspectives, and opportunities, Journal of American Ceramics Society, 100(7), 2017, 2746-2773.

[2] B. Inseemeesak, and A. Rodchanarowan, The influcenc of aluminium dross on cement paste's porosity, Advanced Materials Research, 747, 2013, 445-448.

[3] P. Muangtong, S. Sujjavanich, S. Boonsalee, S. Poomiapiradee, D. Chaysuwan, Effect of fine bagasse ash on the workability and compressive strength of mortars, Chiang Mai Journal of Science, 40(1), 2013, 126-134.

[4] N, Phonphuak, S. Kanyakam, and P. Chindrapasirt, Utilization of waste glass to enhance physical-mechanical properties of fired clay brick. Journal of Cleaner Production, 112, 2016, 3057-3062

[5] A. Aliabdo, M. Elmoaty, A. Aboshama, Utilization of waste glass powder in the production of cement and concrete. Construction and Building Materials, 124, 2016, 866-877.

[6] M. Aiello, F. Leuzzi, G. Centonze, and A. Maffezzoli, Use of steel fibers recovered from waste tyres as reinforcement in concrete: Pull-out behavior, compressive and flexural strength, Waste Management, 29, 2009,1960-1970.

[7] G.Bastos, F. Patino-Berbeito, F. Patino-Cambeiro, and J. Armesto, Admixtures in cementmatrix composites for mechanical reinforcement, sustainability,and smart features, Materials, 9(12), 2016, 1-27.

[8] S. Nontananandh, N. Yoobanpot, D. Chaysuwan, and K. Thongdaeng, Influence of fineness of cement produced from industrial wastes on strength of mortar, Kasetsart Journal-Natural Science, 45(4), 2011, 762-772.

[9] H. Soto, and J.M. Toguri, Aluminum recovery from dross by flotation. Conservation and Recycling, 9(1), 1986, 45-54.

[10] V. T. Ngala, and C. L. Page, Effects of carbonation on pore structure and diffusional properties of hydrated cement pastes, Cement and Concrete Research, 27(7), 1997 9951007.

[11] F. Puertas, M.T. Blanco-Varelaa, and T. Vazqueza, Behavior of cement mortars containing an industrial waste from aluminum refining: Stability in $\mathrm{Ca}(\mathrm{OH})_{2}$ solutions.Cement and Concrete Research, 29, 1999, 1673-1680.

[12] N. Unlu, and M.G. Drouet, Comparison of salt-free aluminum dross treatment processes, Resource and Conservation Recycle, 39, 2002, 61-72.

[13] M.C. Shinzato, and R. Hypolito, Solid waste from aluminum recycling process: characterization and reuse of its economically valuable constituents, Waste Management, $25,2005,37-46$.

[14] V. Kumar, Protection of steel reinforcement for concrete-a review, Corrosion Review, 16(4), 1998, 317-358.

[15] E. G. Debi, U. Bishir, E. Hamzah, and J. Idris, Corrosion and corrosion mitigation of rebar in concrete exposed to marine environment-a review, Engineering Science and Technology: An international Journal, 2(5), 2012, 900-907.

[16] N.B. Singh, V.D. Singh, and S. Rai, Hydration of bagassesash-blendedportland cement, Cement and Concrete Research, 30, 2000, 1485-1488. 
[17] M. Saleem, M. Shameem, S.E. Hussain, and M. Maslehuddint, Effect of moisture, chloride and sulphate contamination on the electrical resistivity of portland cement concrete, Construction and Building Materials, 10(3), 1996, 209-214.

[18] P.E. Tsakiridis, Aluminum salt slag characterization and utilization: A review, Journal of Hazardous Materials, 217-218, 2012, 1-10.

[19] E.M.M Ewais, N.M. Khalil, M.S. Amin, Y.M.Z, Ahmed, and M.A. Barakat, Utilization of aluminum sludge and aluminum slag (dross) for the manufacture ofcalcium aluminate cement. Ceramics International, 35, 2009, 3381-3388.

[20] T.Y. Lo, and H.Z. Cui, Effect of porous lightweight aggregate on strength of concrete, Materials Letters, 58(6), 2004, 916-919.

[21] J.M. Khatib, and P.S. Mangat, Porosity of cement paste cured at $45 \mathrm{oC}$ as a function of location relative to casting position, Cement and Concrete Composites, 25(1), 2003, 97 108.

[22] Rasheeduzzafar, S.S. Al-Saadoun, A.S. Al-Gahtani and F.H. Dakhil, Effect of tricalcium aluminate content of cement on corrosion of reinforcing steel in concrete, Cement and Concrete Research, 20(5), 1990, 723-738.

[23] G. Batis, P. Pantazopoulou, S. Tsivilis, and E. Badogiannis, The effect of metakaolin on the corrosion behavior of cement mortars, Cement and Concrete Composites 27, 2005, 125130.

[24] J.E. Kopanda, and G. MacZura, Production processes, properties and applications for calcium aluminate cements, in L.D. Hart and E. Lense (Eds), Alumina Chemicals Science and Technology Handbook, (New York: American Ceramic Society, 1990), 171-181.

[25] Abdulrasoul Salih Mahdi, Amoxicillin as Green Corrosion Inhibitor for Concrete Reinforced Steel in Simulated Concrete Pore Solution Containing Chloride, International Journal of Advanced Research in Engineering and Technology (IJARET), Volume 5, Issue 6, June (2014), pp. 99-107. 